\title{
Carotenoids Variability of Potato Tubers in Relation to Genotype, Growing Location and Year
}

\author{
Beata Tatarowska ${ }^{1}$ (D) - Dorota Milczarek ${ }^{1} \cdot$ Elżbieta Wszelaczyńska ${ }^{2} \cdot$ Jarosław Pobereżny $^{2}$ • \\ Norbert Keutgen $^{3} \cdot$ Anna Jadwiga Keutgen $^{3} \cdot$ Bogdan Flis $^{1}$
}

Published online: 5 August 2019

(C) The Author(s) 2019

\begin{abstract}
In this study, three cultivars of potato and seven tetraploid breeding lines with different flesh colour were cultivated for three years at four locations in Poland. The objectives of this study were to quantify the levels of total (TC) and individual carotenoids (IC) and to determine the influence of genotype, farming system, growing location, years, and environment on the contents of these components. The aim of this study was also to identify genotypes with stable level of TC and IC. The mean total carotenoids content of tubers ranged between 5.57 and $20.20 \mathrm{mg} \mathrm{kg}^{-1} \mathrm{FW}$ and was influenced by location, year, genotype, and their interactions. Mean values of lutein ranged from 2.92 to $6.66 \mathrm{mg} \mathrm{kg}^{-1} \mathrm{FW}$ and zeaxanthin from 1.44 to $3.05 \mathrm{mg} \mathrm{kg}^{-1} \mathrm{FW}$. The most stable level of total carotenoids content was observed in tubers of breeding line TG-97-403. The most unstable level was found in tubers of cv. Jelly. The ranking of other genotypes depended on the used method. The presented study showed that the contents of carotenoids in potato tubers are significantly affected by environmental factors that cannot be controlled, because these are usually related to the year of cultivation.
\end{abstract}

\section{Resumen}

En este estudio, se sembraron tres variedades de papa y siete líneas de mejoramiento tetraploides con diferente color de pulpa durante tres años en cuatro localidades en Polonia. Los objetivos de este estudio fueron cuantificar los niveles totales (TC) e individuales (IC) de carotenoides, y determinar la influencia del genotipo, sistema de cultivo, localidad, años, y el ambiente, en el contenido de estos componentes. La meta de este estudio también fue la de identificar genotipos con niveles estables de TC e IC. La media del contenido total de carotenoides de los tubérculos fluctuó entre 5.57 y $20.20 \mathrm{mg} \mathrm{kg}-1$ de peso fresco y fue influenciada por la localidad, el año, el genotipo, y sus interacciones. Los valores medios de luteína variaron de 2.92 a $6.66 \mathrm{mg} \mathrm{kg}-1$ en peso fresco, y la zeaxantina de 1.44 a $3.05 \mathrm{mg} \mathrm{kg}-1$ de peso fresco. El nivel más estable del contenido de carotenoides totales se observó en tubérculos de la línea TG-97-403. El nivel mas inestable se encontró en tubérculos de la var. Jelly. Las cifras de otros genotipos dependieron del método usado. El presente estudio mostró que los contenidos de carotenoides en tubérculos de papa se afectan significativamente por factores ambientales que no pueden controlarse, porque generalmente están relacionados por el año de su cultivo.

Keywords Solanum tuberosum $\cdot$ Potato $\cdot$ Carotenoids contents $\cdot$ Lutein $\cdot$ Zeaxanthin $\cdot$ Stability $\cdot$ Tetraploid breeding lines

Beata Tatarowska

b.tatarowska@ihar.edu.pl

1 Plant Breeding and Acclimatization Institute, Młochów Research Center, Platanowa 19, 05-831 Młochów, Poland

2 Department of Microbiology and Food Technology, UTP University of Science and Technology, ul. ks. A. Kordeckiego 20A, 85225 Bydgoszcz, Poland

3 Division of Vegetables and Ornamentals at the Department of Crop Sciences, BOKU - University of Natural Resources and Life Sciences, Gregor Mendel Str. 33, 1180 Vienna, Austria

\section{Introduction}

Potato is one of the major crops in the world (http://faostat.fao. org), which is due to the fact that its tubers are a valuable source of energy and compounds important in human diet. Potato tubers supply mainly carbohydrates, but are also a relatively rich source of amino acids, vitamins, dietary fibre and some minerals. In the potato tubers other components can also be found, among which are the carotenoids and phenolic compounds. These compounds determine flesh colour, which may be red or blue due to the presence of anthocyanins or 
yellow or orange due to carotenoids. In the human diet, phenolic compounds and carotenoids have an antioxidant activity. As pointed out by Brown (2005), potato is not considered as a food rich in antioxidants, but there are some indications that breeding work may lead to increased concentrations of these compounds. In addition, Tatarowska et al. (2014) indicated that the organic farming conditions might favor more active carotenogenesis in potato tubers. Enhanced levels of antioxidants in potato tubers could be significant in those regions of the world, where production of potatoes is growing, because of their importance in the daily diet. On the other hand, obtaining potatoes with a higher content of antioxidant compounds may be especially beneficial for organic production, because the resulting product would be even more valuable in terms of nutritional value.

The color of fresh potato flesh is determined by varying contents of blue or red anthocyanin pigments or results from the accumulation of yellow and orange carotenoids (Brown et al. 2005). The carotenoids of potato are primarily oxygenated carotenoids, also known as xanthophylls (Brown et al. 1993). White-fleshed potatoes have $5-10 \mathrm{mg} \mathrm{kg}^{-1} \mathrm{FW}$ of total carotenoids, while yellow-fleshed potatoes have 10 $35 \mathrm{mg} \mathrm{kg}^{-1} \mathrm{FW}$. Dark-yellow potatoes may contain up to $100 \mathrm{mg} \mathrm{kg}^{-1} \mathrm{FW}$, while the highest recorded contents reached up to $260 \mathrm{mg} \mathrm{kg}^{-1} \mathrm{FW}$ (Brown et al. 1993, 2005, 2006, 2007; Brown 2005, 2008 a, b; Lu et al. 2001; Nesterenko and Sink 2003; Reyes et al. 2005; Van Eck et al. 2007). Lutein, zeaxanthin, violaxanthin and neoxanthin are the major carotenoids present in potatoes whereas $\beta$ carotene is present in trace amounts (Haynes et al. 2011). Lutein and zeaxanthin are components of the human retina (Landrum and Bone 2001), which must be obtained from the diet in order to prevent the age-related macular degeneration (AMD). Green leafy vegetables represent a good dietary source of lutein but a poor source of zeaxanthin, which is found in significant concentrations in a small number of foods. Therefore, potato may be a strategic source for lutein and zeaxanthin, especially as staple food.

The concentration of total and individual carotenoids in potato tubers is affected by several factors such as genotype, agronomic factors, postharvest storage, cooking and processing conditions (Ezekiel et al. 2013; Hamouz et al. 2016; Hejtmánková et al. 2013; Kotíková et al. 2007; Valcarcel et al. 2015).

The objectives of this study was to quantify the level of total and individual carotenoids (lutein and zeaxanthin) in various potato genotypes and to determine the influence of genotype, farming system, growing location, years and environments on the content of these components. The additional aim of this study was to distinguish genotypes with stable level of total and individual carotenoids in potato tubers growing in various environments. This was done by applying two statistical methods, the comparison of which was another additional goal of the work.

\section{Methods}

\section{Plant Material}

For field experiments three cultivars and seven tetraploid breeding lines were used. The tested cultivars were table ones, midearly Satina and Tajfun, and late cultivar Jelly. All three cultivars, the German cultivars Satina and Jelly and the Polish cultivar Tajfun, have yellow tuber flesh. The breeding lines were obtained in a crossing programme performed at the Plant Breeding and Acclimatization Institute - National Research Institute, Młochów Research Center. All lines are complex hybrids that include introgression from multiple sources of tuber bearing Solanum species. Three of the tested breeding lines were white-fleshed and four were yellow-fleshed. From among seven breeding lines used in the study, the tetraploid breeding line TG-97-403, is characterized by a contribution of Solanum phureja in its pedigree, which theoretically is $15.6 \%$. S. phureja was the donor of resistance to Phytophthora infestans in TG-97-403 (Śliwka et al. 2006), and is known as the source of higher carotenoids content of tubers (Bonierbale et al. 2009).

The other six breeding lines used in this work have similarly complex species composition, with the exception of a high contribution of S. phureja. They were derived from crossings involving single pollen parent, which had elevated levels of total carotenoids in tubers $\left(29 \mathrm{mg} \mathrm{kg}^{-1} \mathrm{FW}\right)$, as compared to their seed parents (up to $6.5 \mathrm{mg} \mathrm{kg}^{-1} \mathrm{FW}$ ). The exception was the line 13-VIII-45, which seed parent have also a high TC concentration in tubers $\left(28 \mathrm{mg} \mathrm{kg}^{-1} \mathrm{FW}\right)$. The parentage of breeding lines and TC content in parents (with exception of TG-97-403) are given in Table 1.

\section{Field Trials}

The field trials were carried out during three years (20152017) at four locations in central Poland at Młochów (M), Chwałowice (C) and Radzików (R), and in south-eastern Poland at Boguchwała (B). At locations C and R, the organic cultivation system was applied and in locations $\mathrm{M}$ and $\mathrm{B}$, the integrated system was applied. The details on the geographic location, soil and fertilizer doses for each location are shown in Table 2. In the ecological locations with organic farming, approved pesticides were applied during the vegetation period, i.e. copper fungicides against late blight and pyrethrin (plant extract) or Novodor against Colorado beetle. The Polish company AGRO BIO TEST certified both organic farms. The company implemented a quality system in 2002 according to the norm EN 45011 and received accreditation from the Polish Centre of Accreditation (AC 096). 
Table 1 Parentage of breeding lines used in the study and total carotenoid content in their parents (data not published)

\begin{tabular}{|c|c|c|c|}
\hline \multirow[t]{2}{*}{ Genotype } & & \multicolumn{2}{|c|}{ Total carotenoid content $\left(\mathrm{mg} \mathrm{kg}^{-1} \mathrm{FW}\right)$ of tubers in ${ }^{\mathrm{a}}$} \\
\hline & & Seed parent & Pollen parent \\
\hline 13-VIII-10 & 07-VIII-264 × Nr 10 & 6.5 & 29.0 \\
\hline 13-VIII-27 & 07-VIII-264 × Nr 10 & 6.5 & \\
\hline 13-VIII-45 & $\mathrm{M}-62887 \times \mathrm{Nr} 10$ & 28.0 & \\
\hline 13-VIII-49 & $\mathrm{M}-62910 \times \mathrm{Nr} 10$ & 6.2 & \\
\hline 13-VIII-50 & $\mathrm{M}-62910 \times \mathrm{Nr} 10$ & 6.2 & \\
\hline 13-VIII-60 & $\mathrm{M}-62910 \times \mathrm{Nr} 10$ & 6.2 & \\
\hline TG-97-403 & DG $92-515 \times$ CEC-69 & ne & ne \\
\hline
\end{tabular}

The experimental design was a randomized complete block. In each of two blocks (= repetitions), cultivars and breeding lines were planted in 6 hill plots. Before planting, seed tubers weight was standardized (700 g per hill plot). Tubers were planted in the end of April and harvested after 130 days. Weather conditions during the field experiments in 2014, 2015 and 2016 are shown in Fig. 1.

\section{Total Carotenoid Content (TC)}

TC was estimated for tubers obtained in all field experiments. For each potato breeding line/cultivar and each repetition in each location in each year, three tubers were collected. Tubers were cut into 8 parts. Two fragments were selected for an analysis. Next, these fragments were cut into small cubes and frozen in liquid nitrogen, lyophilized and milled. Total carotenoids were isolated according to the procedure described in PN-90/A-75101/12 standard with modifications. The procedure has been shortened and limited to extraction with hexane: TC were extracted from $3 \mathrm{~g}$ of freeze-dried tissue in a glass flask with $50 \mathrm{ml}$ of hexane for $24 \mathrm{~h}$ in the dark. Total carotenoids concentrations in the solvent were evaluated spectrophotometrically with a UV-Vis HITACHI U-1900 spectrophotometer at $450 \mathrm{~nm}$. All analyses were made with three technical repetitions each.

\section{Individual Carotenoid Content (Lutein and Zeaxanthin) (IC)}

IC was estimated for tubers obtained in field experiments for each breeding line/cultivar and each repetition in each location, but only in 2014 and 2015. Carotenoids were extracted from $2 \mathrm{~g}$ of freeze-dried tissue in the $50 \mathrm{ml}$ falcon tube with $5 \mathrm{ml}$ of ethanol (for HPLC) in $24 \mathrm{~h}$ in the dark. Then, $2 \mathrm{ml}$ of the eluent was centrifuged on the filtration column (A\&A Biotechnology, Poland) at 600 RPM for $30 \mathrm{~s}$.

A volume of $8 \mu \mathrm{l}$ of filtered sample was separated on a Shimadzu Prominence HPLC (Shimadzu, Japan) using a reversed-phase Phenomenex Luna $4.6 \mu \mathrm{m}$ 100A $150 \times$ 4.6 mm HPLC at $50{ }^{\circ} \mathrm{C}$ column temperature. The flow rate

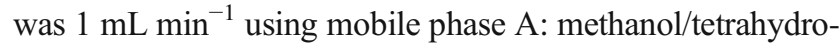
furan $/$ water $=45 / 10 / 45(\mathrm{v} / \mathrm{v} / \mathrm{v})$ and $\mathrm{B}$ : tetrahydrofuran. The gradient was as follows: $0 \% \mathrm{~B}$ increasing to $50 \%$ over $25 \mathrm{~min}$, equilibrated to $0 \% \mathrm{~B}$ for $5 \mathrm{~min}$ and held at $0 \%$ for

Table 2 Geographic, soil, fertilization and fore crops data for locations and years

\begin{tabular}{|c|c|c|c|c|}
\hline Location & Geographic coordinates & Type of soil & Year & Doses of fertilizers $\mathrm{kg} \mathrm{ha}^{-1}$ \\
\hline \multirow[t]{3}{*}{ B } & \multirow[t]{3}{*}{$49^{\circ} 58^{\prime} 59^{\prime \prime} \mathrm{N} 21^{\circ} 56^{\prime} 23^{\prime \prime} \mathrm{E}$} & \multirow[t]{3}{*}{ Cambisols } & 2014 & $\begin{array}{l}120 \mathrm{~N}, 60 \mathrm{P}_{2} \mathrm{O}_{5}, 180 \mathrm{~K}_{2} \mathrm{O}+15 \mathrm{t} \text { composted manure + foliar fertilization } \\
\text { Adob } \mathrm{Cu} \text {, Adob Mn, Adob S, Basfoliar } 36 \text { Extra }\end{array}$ \\
\hline & & & 2015 & $\begin{array}{l}120 \mathrm{~N}, 60 \mathrm{P}_{2} \mathrm{O}_{5}, 180 \mathrm{~K}_{2} \mathrm{O}+\text { foliar fertilization Basfoliar } 36 \text { Extra i Basfoliar } \\
12-4-6+\mathrm{S}+\text { amino }\end{array}$ \\
\hline & & & 2016 & $\begin{array}{l}120 \mathrm{~N}, 60 \mathrm{P}_{2} \mathrm{O}_{5}, 180 \mathrm{~K}_{2} \mathrm{O}+\text { foliar fertilization Basfoliar } 36 \text { Extra, Basfoliar } \\
12-4-6+\mathrm{S}+\text { amino }\end{array}$ \\
\hline \multirow[t]{3}{*}{$\mathrm{C}$} & \multirow[t]{3}{*}{$51^{\circ} 10^{\prime} 56^{\prime \prime} \mathrm{N} 21^{\circ} 18^{\prime} 17^{\prime \prime} \mathrm{E}$} & \multirow[t]{3}{*}{ Cambisols } & 2014 & $25 \mathrm{t} /$ ha composted manure \\
\hline & & & 2015 & \\
\hline & & & 2016 & \\
\hline \multirow[t]{3}{*}{ M } & \multirow[t]{3}{*}{$52^{\circ} 3^{\prime} 0^{\prime \prime} \mathrm{N} 20^{\circ} 46^{\prime} 7^{\prime \prime} \mathrm{E}$} & \multirow[t]{3}{*}{ Podzols } & 2014 & $90 \mathrm{~N}, 110 \mathrm{P}_{2} \mathrm{O} 5,180 \mathrm{~K}_{2} \mathrm{O}$ \\
\hline & & & 2015 & $90 \mathrm{~N}, 110 \mathrm{P}_{2} \mathrm{O}_{5}, 180 \mathrm{~K}_{2} \mathrm{O}$ \\
\hline & & & 2016 & $90 \mathrm{~N}, 110 \mathrm{P}_{2} \mathrm{O}_{5}, 180 \mathrm{~K}_{2} \mathrm{O}$ \\
\hline \multirow[t]{3}{*}{$\mathrm{R}$} & \multirow[t]{3}{*}{$52^{\circ} 13^{\prime} 38^{\prime} \mathrm{N} \mathrm{20} 36^{\prime} 55^{\prime \prime E}$} & \multirow[t]{3}{*}{ Phaeozem } & 2014 & $25 \mathrm{t} / \mathrm{ha}$ composted manure \\
\hline & & & 2015 & \\
\hline & & & 2016 & \\
\hline
\end{tabular}


Fig. 1 Precipitation (total monthly in $\mathrm{mm}$ ) and temperature (monthly average in ${ }^{\circ} \mathrm{C}$ ) during the 2014, 2015 and 2016 potato growing season in Boguchwała (B), Chwałowice (C), Młochów (M) and Radzików (R)
2014

2015

2016
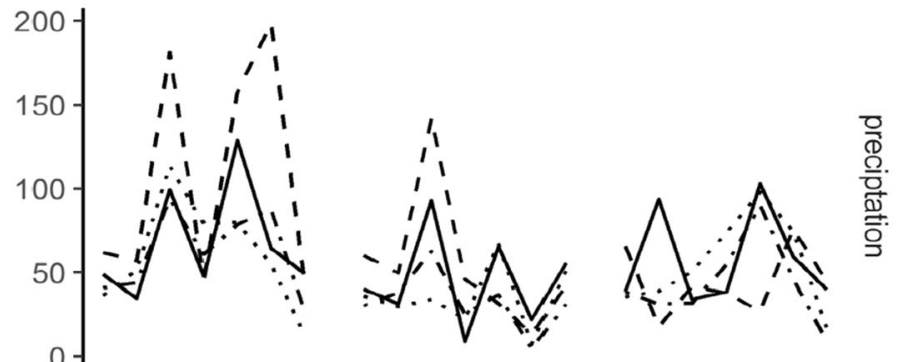

location

- B

$--\mathrm{C}$

$\cdots \mathrm{M}$

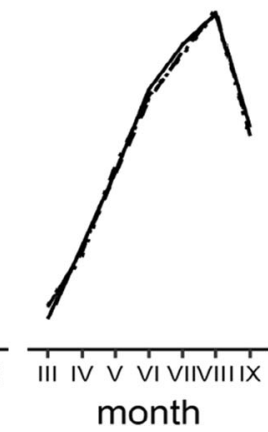

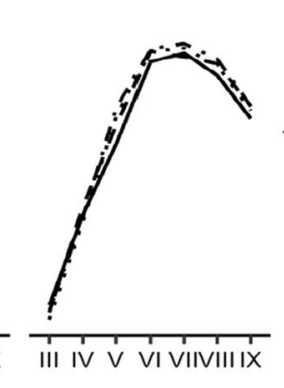

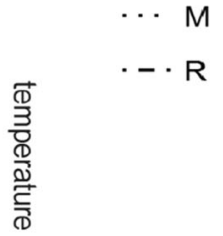

$5 \mathrm{~min}$. The UV/Vis absorbance detector collected data at $452 \mathrm{~nm}$. Lutein and zeaxanthin quantifications were performed by using a standard curve ranging from 0.5 to $4 \mu \mathrm{g} \mathrm{ml}^{-1}$. The standard curve was prepared for lutein and zeaxanthin standards (LGC Standards, UK). Quantification was performed using LC solution software (Shimadzu, Japan). All analyses were made with three technical repetitions each.

\section{Flesh Colour Measurement}

From each potato breeding line/cultivar, five tubers in two replications were evaluated. Before evaluation, tubers were removed from cold storage and allowed to warm overnight to reduce condensation. Tubers were sliced in half from the apical to the distal end, blotted dried, and evaluated for yellow-flesh intensity using a Colorimeter. For each potato clone/cultivar 60 measurements were taken. Intensity of potato flesh coloration was assessed using the Minolta CR-400 Colorimeter (Osaka, Japan)). The yellowness index was calculated according to the formula:

$Y I_{E 313}=\frac{100\left(C_{x} X-C_{z} Z\right)}{Y}$

where $C_{x}$ and $C_{z}$ are illuminant- and observer- specific constants; $X, Y, Z$ - trichromatic values (ASTM 2005).

\section{Statistical Analysis}

Firstly, for TC, IC and yellowness index the three-way ANOVA was performed to reveal significance of fixed effects of genotype (G), location (L) and year of experiment (Y) and their interactions. The design was fully balanced and genotypes were nested in combinations of years and locations. The TC values did not fulfill the assumptions of homogeneity of variances and were log transformed before ANOVA. In addition, in tables, the re-transformed mean values of TC content are shown. In the case of lutein, some measurements of its content were below the limit of quantification (LOQ). Discarding such observations from data analysis may lead to biased estimates, incorrect standard errors and incorrect inferences. To avoid such problems, the procedure of multiple imputation was applied before ANOVA.

The stability analyses for TC and lutein content were performed with two methods. The phenotypic stability of the quantitative trait can be explored by the use of many of statistical methods allowing the analysis of genotype by environment interaction. However, these methods may produce different results (Fasahat et al. 2015). The first one was AMMI (additive main effects and multiplicative interaction) analysis (Gauch 2006), which is widely used in stability analyses. This is a two-step method. The first step is the procedure of fitting genotypes and environments effects by usual ANOVA. In the second step, principal components analysis (PCA) fits multiplicative effects for the genotype by environment $(G \times E)$ interaction. The PCA section of AMMI requires that $\mathrm{G} \times \mathrm{E}$ effects are arranged on a twoway matrix. In this publication such an arrangement was achieved by defining environments as combination of location and year $(\mathrm{E}=\mathrm{Y} \times \mathrm{L})$.

The AMMI extracts new variables (PCs). Those of the PCs that explain the largest part of the interaction induced variability are graphically represented (these are usually the first two PCs) and are used for constructing a biplot. The AMMI model 
does not provide quantitative measures useful for ranking genotypes, but this can be done by using the AMMI stability value (ASV) (Purchase et al. 2000). The ASV is the distance between a point corresponding to a particular genotype and the origin of the biplot using the first two PCs.

The other measure of stability of the TC content was based on the Scheffé-Caliński model, in which genotype means are fixed, whereas environmental effects are random (mixed model) (Mądry and Kang 2005). In this procedure, the ANOVA is the first step. Then, the evaluation of significance of individual genotypes contribution into interactions effects is performed. The interactions include those between genotype $(G)$ and year $(\mathrm{Y})$, genotype and location $(\mathrm{L})$ and the highest order interaction between $\mathrm{G}, \mathrm{Y}$ and $\mathrm{L}(\mathrm{G} \times \mathrm{Y} \times \mathrm{L}=\mathrm{G} \times \mathrm{E})$. For each genotype, the size of these interaction effects are measured by appropriate $\mathrm{F}$ statistic. The stable genotype has a low contribution to overall $\mathrm{G} \times \mathrm{E}$ interaction (the $\mathrm{G} \times \mathrm{E}$ effect for a specific genotype is statistically insignificant or, what is equivalent, the respective value of $\mathrm{F}_{\mathrm{G} \times \mathrm{E}}$ statistics is accordingly low). The further steps are joint regression analysis, which determines to what extent the regression explains $\mathrm{G} \times \mathrm{E}$ and canonical variables analysis, which is essentially similar to principle component analysis (including graphical output in the form of biplots), which are not presented.

The ANOVA and AMMI were done with the R program (De Mendiburu 2015; R Core Team 2015). The analysis based on the Scheffé-Caliński model was generated in the program Sergen 3 (Caliński et al. 1998). In the case of lutein, the procedure of the multiple imputations was performed by $\mathrm{R}$ package Hmisc (Harrel et al. 2016). For graphs, ggplot package of R was used (Wickham 2009).

\section{Results}

\section{Tuber Flesh Colour}

The yellowness index of the evaluated white-flashed potato breeding lines ranged from 37.1 to 42.7 and in yellow-flashed lines/cultivars ranged from 55.0 to 62.5 (Table 3). The positive correlation between yellowness index and TC was very high $(\mathrm{r}=$ $0.93^{* *}$ ), and between yellowness index and lutein content was lower and moderate $\left(\mathrm{r}=0.60^{* *}\right)$. The three breeding lines with white tuber flesh formed a distinct group with the yellowness indices significantly different from those found for yellowfleshed potatoes. However, the yellow-fleshed group of lines/ cultivars was not uniform in respect of this index (Table 3).

\section{Total and Individual Carotenoids Contents of Potato Clones and Cultivars}

Ten potato cultivars/breeding lines were analysed for their total and individual (lutein and zeaxanthin) carotenoid content. For the
Table 3 Yellowness index of ten genotypes grown in four locations in years 2014-2016

\begin{tabular}{llllll}
\hline Genotype & Mean & \pm & sd & & Tuber flesh colour \\
\hline 13-VIII-10 & 62.5 & \pm & 1.48 & $\mathrm{a}$ & yellow \\
TG-97-403 & 60.3 & \pm & 1.98 & ab & yellow \\
Satina & 58.9 & \pm & 2.73 & $\mathrm{~b}$ & yellow \\
Jelly & 58.0 & \pm & 2.95 & $\mathrm{bc}$ & yellow \\
13-VIII-49 & 55.8 & \pm & 1.97 & $\mathrm{~cd}$ & yellow \\
13-VIII-60 & 55.5 & \pm & 2.63 & $\mathrm{~cd}$ & yellow \\
Tajfun & 55.0 & \pm & 3.16 & $\mathrm{~d}$ & yellow \\
13-VIII-45 & 42.7 & \pm & 3.10 & $\mathrm{e}$ & white \\
13-VIII-50 & 39.5 & \pm & 1.66 & $\mathrm{f}$ & white \\
13-VIII-27 & 37.1 & \pm & 2.37 & $\mathrm{f}$ & white \\
\hline
\end{tabular}

${ }^{a}$ The higher value of YI the more yellow is tuber flesh. Mean values with the same letter are not different at $p<0.05$

TC content, the three-way ANOVA revealed highly significant effects for location, year, genotype and their interactions (results not shown).

Mean values of TC for genotypes, locations and environments are presented in Table 4 . The mean TC content of tubers ranged from $5.57 \mathrm{mg} \mathrm{kg}^{-1} \mathrm{FW}$ (in 13-VIII-27) to $20.20 \mathrm{mg} \mathrm{kg}$ ${ }^{-1} \mathrm{FW}$ (in 13-VIII-10). The higher levels of TC concentration were found for yellow-fleshed cultivars with an average mean value ranging from $9.23 \mathrm{mg} \mathrm{kg}^{-1} \mathrm{FW}$ for $\mathrm{cv}$. Tajfun to $20.20 \mathrm{mg} \mathrm{kg}^{-1} \mathrm{FW}$ for breeding line 13-VIII-10. The TC level in white-fleshed potatoes varied from $5.57 \mathrm{mg} \mathrm{kg}^{-1} \mathrm{FW}$ to $8.68 \mathrm{mg} \mathrm{kg}^{-1} \mathrm{FW}$. The homogeneous groups of genotypes distinguished by the Tukey test are almost identical to those of the yellowness index.

The highest concentration of TC was found in tubers harvested in location $\mathrm{B}$ with integrated cultivation system (14.05 mg kg $\left.\mathrm{m}^{-1} \mathrm{FW}\right)$ and in location $\mathrm{C}$ with organic farming (13.33 mg kg${ }^{-1} \mathrm{FW}$ ), and the lowest concentration was in location $\mathrm{M}$ with integrated cultivation system $\left(8.74 \mathrm{mg} \mathrm{kg}^{-1}\right.$ FW). When environments (combinations of location and year) are considered, the concentrations of TC were the lowest in integrated system M_14 and organic R_14, and the highest in integrated system B_15 and B_16 (Table 4).

As for lutein, the three-way ANOVA showed highly significant or significant effects of genotype, location and all interactions. The exception was the insignificant effect of year (results not shown in tables). The highest levels of lutein were noted for yellow-fleshed breeding line 13-VIII-10 $\left(6.66 \mathrm{mg} \mathrm{kg}^{-1} \mathrm{FW}\right)$ and the lowest level for white-fleshed 13-VIII-27 $\left(2.92 \mathrm{mg} \mathrm{kg}^{-1}\right.$ FW). However, the group of seven genotypes with the lowest lutein content of tubers (Table 5) contains individuals with a high yellowness index (yellow fleshed 'Jelly') and with low values of this index (white fleshed 13-VIII-50).

The highest content of lutein was found in tubers harvested in integrated system location $\mathrm{B}\left(5.42 \mathrm{mg} \mathrm{kg}^{-1} \mathrm{FW}\right)$ and 
Table 4 Mean values of TC content $\left(\mathrm{mg} \mathrm{kg}^{-1} \mathrm{FW}\right)$ of potato tubers from 10 genotypes grown in Boguchwała (B), Chwałowice (C), Młochów (M) and Radzików (R) in 2014, 2015 and 2016

\begin{tabular}{|c|c|c|c|c|c|c|c|c|c|c|c|c|c|c|}
\hline \multirow[t]{2}{*}{ Genotype } & \multicolumn{6}{|c|}{ Integrated system } & \multicolumn{6}{|c|}{ Organic system } & \multicolumn{2}{|l|}{ Mean } \\
\hline & B_14 & B_15 & B_16 & M_14 & M_15 & M_16 & C_14 & C_15 & C_16 & R_14 & R_15 & R_16 & & \\
\hline 13-VIII-10 & 23.12 & 25.23 & 25.42 & 13.64 & 16.21 & 18.83 & 27.74 & 23.35 & 18.85 & 16.98 & 23.71 & 15.19 & 20.20 & a \\
\hline Satina & 23.81 & 20.07 & 22.26 & 8.49 & 11.53 & 13.25 & 28.38 & 12.17 & 31.51 & 12.98 & 17.54 & 29.37 & 17.79 & $\mathbf{a b}$ \\
\hline TG-97-403 & 12.31 & 25.93 & 22.97 & 5.97 & 19.31 & 19.38 & 13.92 & 20.61 & 23.28 & 10.20 & 22.16 & 22.70 & 16.95 & $\mathbf{a b}$ \\
\hline 13-VIII-49 & 18.63 & 17.36 & 27.44 & 6.04 & 16.97 & 23.51 & 11.90 & 20.36 & 12.71 & 10.03 & 14.67 & 10.72 & 14.72 & bc \\
\hline Jelly & 8.27 & 24.21 & 33.53 & 2.42 & 8.64 & 11.69 & 25.14 & 9.33 & 40.02 & 1.92 & 9.08 & 31.75 & 11.96 & cd \\
\hline 13-VIII-60 & 6.91 & 16.23 & 18.66 & 2.61 & 13.36 & 21.04 & 5.55 & 15.92 & 27.24 & 6.08 & 16.67 & 17.09 & 11.67 & cd \\
\hline Tajfun & 5.13 & 12.66 & 14.93 & 3.18 & 6.85 & 26.43 & 4.08 & 6.96 & 22.97 & 5.78 & 6.92 & 26.23 & 9.23 & de \\
\hline 13-VIII-50 & 5.40 & 17.32 & 10.57 & 4.34 & 10.72 & 10.73 & 6.22 & 14.42 & 8.28 & 3.88 & 13.12 & 9.83 & 8.68 & e \\
\hline 13-VIII-45 & 4.58 & 15.80 & 8.94 & 2.10 & 14.85 & 8.11 & 6.26 & 12.25 & 9.11 & 3.94 & 19.83 & 7.41 & 7.97 & e \\
\hline 13-VIII-27 & 4.14 & 8.45 & 8.63 & 2.15 & 4.12 & 5.30 & 4.60 & 11.82 & 4.87 & 4.28 & 8.40 & 6.62 & 5.57 & f \\
\hline Environment mean & $9.07 d$ & $17.45 \mathrm{a}$ & $17.52 \mathrm{a}$ & $4.18 f$ & 11.23bcd & 14.23ab & $10.29 \mathrm{~cd}$ & 13.84abc & $16.63 a$ & $6.31 \mathrm{e}$ & 14.10abc & $15.39 \mathrm{ab}$ & & \\
\hline Location mean & 14.05 & & & 8.74 & & & 13.33 & & & 11.10 & & & & \\
\hline
\end{tabular}

The mean values followed by the same letter do not differ significantly (according to Tukey test)

organic location $\mathrm{C}\left(4.27 \mathrm{mg} \mathrm{kg}^{-1} \mathrm{FW}\right)$ and the lowest - in organic $\mathrm{R}$ and integrated $\mathrm{M}$ (3.69 and $3.61 \mathrm{mg} \mathrm{kg}^{-1} \mathrm{FW}$ ) respectively. The lutein content in environments ranged from $3.15 \mathrm{mg} \mathrm{kg}{ }^{-1} \mathrm{FW}$ in $\mathrm{R} \_15$ to $5.78 \mathrm{mg} \mathrm{kg}^{-1} \mathrm{FW}$ in B_15 (Table 4). Lutein accounted on average for approximately $35 \%$ of the TC content and the concentrations of lutein and TC correlated highly $\left(\mathrm{r}=0.87^{* *}\right.$ for years 2014 and 2015). However, in some clones proportion of lutein in TC was $46 \%$ and $55 \%$ as in case of white fleshed lines 13-VIII-27 and $13-$ VIII-50.
Due to a very large number of measurements below the LOQ, ANOVA for zeaxanthin content was not performed. Zeaxanthin content in potato genotypes ranged from $1.44 \mathrm{mg} \mathrm{kg}^{-1} \mathrm{FW}$ (in 13-VIII-60 in C 14) to $3.05 \mathrm{mg} \mathrm{kg}^{-1}$ FW (in 13-VIII-50 in C_14) (Table 6). In many environments the zeaxanthin concentration was below the limit of quantification. Zeaxanthin content was low, but highly positively correlated with TC content $(\mathrm{r}=0.92 * *$, taking into account the years 2014 and 2015 as well as values above the limit of quantification). Zeaxanthin did not contribute significantly to

Table 5 Mean values of lutein content ( $\mathrm{mg} \mathrm{kg}^{-1} \mathrm{FW}$ ) of potato tubers from 10 genotypes grown in Boguchwała (B), Chwałowice (C), Młochów (M) and Radzików (R) in 2014 and 2015

\begin{tabular}{|c|c|c|c|c|c|c|c|c|c|c|}
\hline \multirow[t]{2}{*}{ Genotype } & \multicolumn{4}{|c|}{ Integrated system } & \multicolumn{4}{|c|}{ Organic system } & \multicolumn{2}{|l|}{ Mean $^{1}$} \\
\hline & B_14 & B_15 & M_14 & M_15 & C_14 & C_15 & R_14 & R_15 & & \\
\hline 13-VIII-10 & 10.13 & 5.32 & 3.66 & 5.32 & 8.54 & 6.35 & 10.41 & 3.56 & 6.66 & $\mathbf{a}$ \\
\hline Satina & 8.19 & 7.75 & 3.16 & 3.91 & 10.66 & 3.81 & 6.04 & 4.66 & 6.02 & $\mathbf{a b}$ \\
\hline TG-97-403 & 5.41 & 11.13 & 2.75 & 5.76 & 4.54 & 5.41 & 3.44 & 3.88 & 5.39 & $\mathbf{b}$ \\
\hline 13-VIII-50 & 3.16 & 10.03 & 3.82 & 3.41 & 3.13 & 2.60 & 2.60 & 2.91 & 3.81 & c \\
\hline 13-VIII-49 & 4.41 & 3.82 & 2.75 & 3.44 & 3.82 & 3.91 & 4.10 & 2.60 & 3.59 & c \\
\hline Tajfun & $\operatorname{loq}^{2}$ & 4.75 & $\operatorname{loq}^{2}$ & 3.22 & 2.47 & 2.66 & $\operatorname{loq}^{2}$ & 2.50 & 3.46 & c \\
\hline Jelly & 2.38 & 4.82 & 2.91 & 3.16 & 5.50 & 2.53 & 2.81 & 2.66 & 3.25 & c \\
\hline 13-VIII-60 & 3.69 & 3.63 & $\operatorname{loq}^{2}$ & 2.91 & 2.66 & 3.19 & 2.69 & 3.28 & 3.13 & c \\
\hline 13-VIII-27 & 3.19 & 3.22 & $\operatorname{loq}^{2}$ & 2.56 & 2.94 & 2.85 & 3.78 & 3.38 & 2.94 & c \\
\hline 13-VIII-45 & 2.60 & 3.38 & $\operatorname{loq}^{2}$ & 2.88 & 2.72 & 3.63 & 3.10 & 2.81 & 2.93 & c \\
\hline Mean $^{1}$ & 5.05ab & $5.78 \mathrm{a}$ & 2.91d & $3.65 \mathrm{~cd}$ & $4.84 b$ & $3.69 \mathrm{~cd}$ & $3.89 \mathrm{c}$ & $3.15 \mathrm{~cd}$ & & \\
\hline Location mean & 5.42 & & 3.27 & & 4.27 & & 3.52 & & & \\
\hline
\end{tabular}

\footnotetext{
${ }^{1}$ Due to presence values below the limit of quantification, the procedure of multiple imputation preceded further statistical analyses (ANOVA as well as calculation of mean values). The mean values followed by the same letter do not differ significantly (according to Tukey test)

${ }^{2}$ The values below the limit of quantification
} 
Table 6 Mean values of zeaxanthin content $\left(\mathrm{mg} \mathrm{kg}^{-1} \mathrm{FW}\right)$ of potato tubers from 10 genotypes grown in Boguchwała (B), Chwałowice (C), Młochów (M) and Radzików (R) in 2014 and 2015

\begin{tabular}{|c|c|c|c|c|c|c|c|c|}
\hline \multirow[t]{2}{*}{ Genotype } & \multicolumn{4}{|c|}{ Integrated system } & \multicolumn{4}{|c|}{ Organic system } \\
\hline & B_14 & B_15 & M_14 & M_15 & C_14 & $C_{-} 15$ & R_14 & R_15 \\
\hline TG-97-403 & loq & 1.84 & loq & 1.95 & loq & 1.80 & loq & loq \\
\hline 13-VIII-50 & 2.96 & $\operatorname{loq}$ & loq & loq & 3.05 & $\operatorname{loq}$ & 2.02 & loq \\
\hline 13-VIII-27 & $\operatorname{loq}$ & loq & loq & loq & $\operatorname{loq}$ & loq & $\operatorname{loq}$ & loq \\
\hline 13-VIII-49 & loq & loq & loq & loq & loq & 1.98 & loq & loq \\
\hline 13-VIII-45 & 1.72 & loq & loq & loq & 1.88 & loq & 2.06 & loq \\
\hline 13-VIII-60 & loq & loq & loq & loq & 1.44 & loq & loq & loq \\
\hline Satina & 2.38 & 1.98 & loq & loq & 2.48 & loq & 2.44 & loq \\
\hline 13-VIII-10 & 1.75 & 1.73 & loq & 1.88 & 1.75 & 2.03 & 2.03 & 1.74 \\
\hline Tajfun & loq & 1.96 & loq & loq & loq & loq & loq & loq \\
\hline Jelly & 2.38 & 1.99 & $\operatorname{loq}$ & $\operatorname{loq}$ & 2.14 & $\operatorname{loq}$ & 2.23 & $\operatorname{loq}$ \\
\hline
\end{tabular}

loq - values below the limit of quantification

the total carotenoid content in the tested genotypes. The lowest contribution was in tubers of Tajfun, Jelly and white fleshed clones (from 3.4 to $5.5 \%$ ), and the highest in tubers of TG-97-403 (9\%) and 13-VIII-10 (11.5\%).

\section{Stability of TC and Lutein Content}

The stability of TC content was evaluated by using AMMI and the mixed model of Schaffe-Calinski. The first step of AMMI was ANOVA, based on the model with three sources of variation, G, E (combination of locations and year) and the interaction $\mathrm{G} \times \mathrm{E}$, which accounted for $29 \%, 35 \%$ and $27 \%$ of total sums of squares, respectively (Table 7). The final output of AMMI is graphically represented in the form of the biplot
(Fig. 2), which have been completed by providing the quantitative measure of ASV. In the case of tested genotypes, their distance from the biplot origin was between two extremes: the highest was found for Jelly and the lowest for TG-97-403 (the highest and smallest ASV, respectively). This distance for Satina, Tajfun and 13-VIII-10 is much higher than for the rest of the genotypes, but no other genotype was as close to the origin as TG-97-403 (Fig. 2). The ASV and ranks of individual genotypes are given in Table 8 .

In the biplot, the environments are presented as vectors, each corresponding to the combination of location and year (Fig. 2). The vectors have usually the same direction and angles between them are acute (indicating correlation), if those vectors represents the same year. It is clearly visible for environments from 2015 and 2016, in which outliers were B_15 and M_16. In the case of 2014, the environments formed the less related group and the most atypical environment was $C_{-} 14$. On the contrary, vectors for the same location and different years have obtuse angles or right angles with exception of B_16 and B_15, M_15 and M_16 or R_14 and R_15 (Fig. 2).

The second stability parameter was the value of the $F_{G \times E}$ statistic obtained from analysis of the Scheffé-Caliński mixed model. The initial step was ANOVA, in which the total sum of squares (SS) was partitioned differently as compared to AMMI (Table 7). From among environmental factors, Y accounted for $24 \%$ of total sum of squares, while contributions of $\mathrm{L}$ and $\mathrm{E}(=\mathrm{Y} \times \mathrm{L})$ were much lower (Table 6$)$. As for interactions between $\mathrm{G}$ and $\mathrm{Y}$ or $\mathrm{L}$, the dominant contribution in total SS had the interaction $\mathrm{G} \times \mathrm{Y}$.

In the second step, it was found that for one genotype, Jelly, its contribution in $\mathrm{G} \times \mathrm{E}$ was significant (significant value of $\mathrm{F}_{\mathrm{G} \times \mathrm{E}}$ ) (Table 8). This effect of Jelly was not explained by the regression. As for other interactions, only for the breeding

Table 7 Significance of variance parameters for total carotenoids (TC) and lutein for 10 genotypes grown in 4 locations in 3 years

\begin{tabular}{|c|c|c|c|c|c|c|c|c|}
\hline \multirow[t]{3}{*}{ Source of variation } & \multicolumn{4}{|c|}{ ANOVA for Scheffe-Caliński model } & \multicolumn{4}{|c|}{ ANOVA in AMMI analysis } \\
\hline & \multicolumn{2}{|l|}{$\mathrm{TC}$} & \multicolumn{2}{|l|}{ Lutein } & \multicolumn{2}{|l|}{ TC } & \multicolumn{2}{|l|}{ Lutein } \\
\hline & Significance & $\%$ of SS & Significance & $\%$ of SS & Significance & $\%$ of SS & Significance & $\%$ of SS \\
\hline Genotype (G) & $*$ & $30 \%$ & $* * *$ & $30 \%$ & $* *$ & $29 \%$ & $* * *$ & $35 \%$ \\
\hline Location (L) & $\mathrm{ns}$ & $7 \%$ & $* * *$ & $11 \%$ & ni & & ni & \\
\hline Year $(Y)$ & $* * *$ & $24 \%$ & ns & $0 \%$ & ni & & ni & \\
\hline $\mathrm{G} \times \mathrm{L}$ & $* *$ & $5 \%$ & $* * *$ & $13 \%$ & ni & & ni & \\
\hline $\mathrm{G} \times \mathrm{Y}$ & $* * *$ & $15 \%$ & $* * *$ & $11 \%$ & ni & & ni & \\
\hline Environment $\mathrm{E}(=\mathrm{Y} \times \mathrm{L})$ & $* *$ & $3 \%$ & $* *$ & $3 \%$ & $* *$ & $35 \%$ & $* * *$ & $18 \%$ \\
\hline $\mathrm{G} \times \mathrm{E}$ & $* *$ & $8 \%$ & $* * *$ & $14 \%$ & $* *$ & $27 \%$ & $* * *$ & $39 \%$ \\
\hline error & na & $8 \%$ & na & $18 \%$ & na & $8 \%$ & na & $8 \%$ \\
\hline
\end{tabular}

***, *** - significant at $P=0.05$ or 0.01 or 0.001 , respectively; $n s$ not significant, $n i$ the source of variation not included in the model, na not applicable SS sum of squares. Both ANOVA models differently partitions the variation. SS for E in AMMI analysis approximately corresponds to the sum for L, Y and $\mathrm{E}$ in mixed model ANOVA;

$\mathrm{SS}$ for $\mathrm{G} \times \mathrm{E}$ in $\mathrm{AMMI}$ corresponds to the sum for interactions $\mathrm{G} \times \mathrm{L}, \mathrm{G} \times \mathrm{Y}$ and $\mathrm{G} \times \mathrm{E}$ in mixed model ANOVA 
Fig. 2 Biplot of 10 potato genotypes and 12 environments (combinations of location and year) for TC concentration

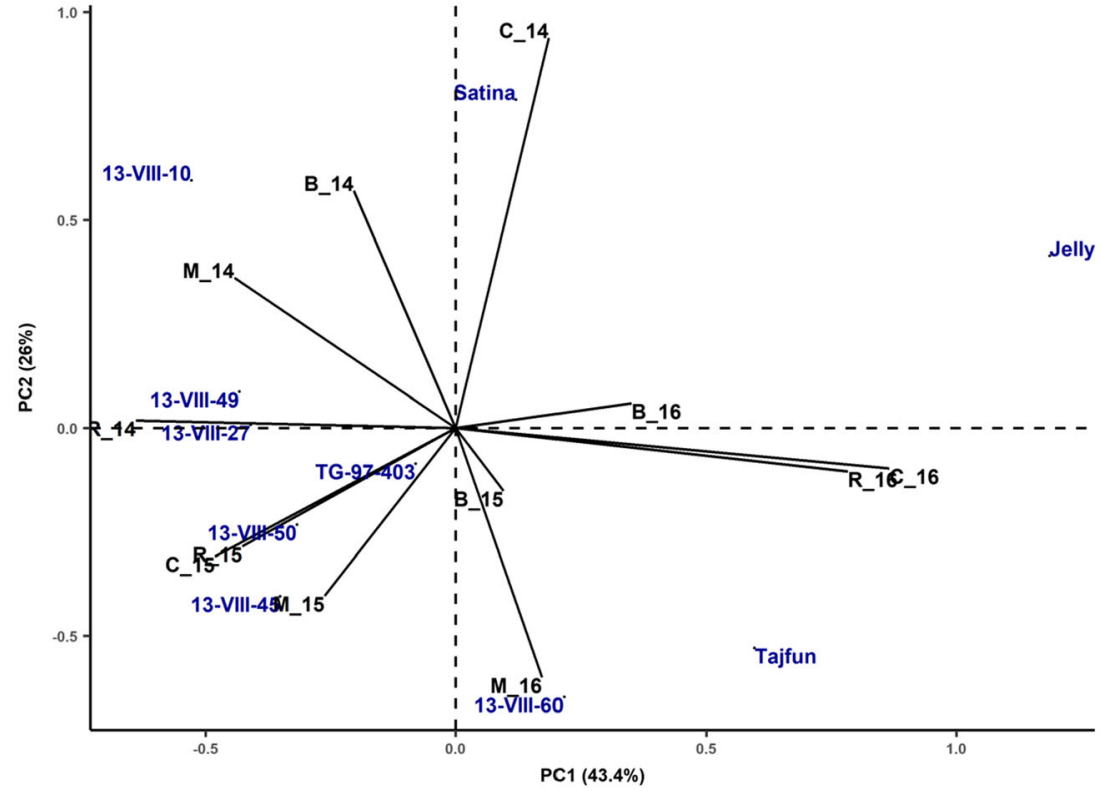

lines 13-VIII-10 and 13-VIII-45 the significant contribution in the on $\mathrm{G} \times \mathrm{Y}$ was found.

The values of $\mathrm{F}_{\mathrm{G} \times \mathrm{E}}$ and AVS were highly correlated (Spearman's rank correlation coefficient was $r_{s}=0.70^{*}$ ).

The analysis AMMI was also conducted for lutein concentration (Table 7, Fig. 3 and Table 9). ANOVA revealed that genotypes, environment and their interactions accounted for $35 \%, 18 \%$ and $39 \%$ of total SS, respectively (Table 7). Compared to the TC analysis, these contributions were much smaller for the environment and much larger in the case of the interaction $\mathrm{G} \times \mathrm{E}$.

Table $8 \quad \mathrm{ASV}$ and $\mathrm{F}_{\mathrm{G} \times \mathrm{E}}$ for $\mathrm{TC}\left(\mathrm{mg} \mathrm{kg}^{-1} \mathrm{FW}\right)$ in potato tubers evaluated in 12 environments

\begin{tabular}{|c|c|c|c|c|c|c|}
\hline \multirow[t]{2}{*}{ Genotype } & \multirow{2}{*}{$\begin{array}{l}\text { Mean TC } \\
\text { content }\end{array}$} & \multicolumn{2}{|l|}{$\mathrm{ASV}^{\mathrm{a}}$} & \multicolumn{2}{|c|}{$F_{G \times E}^{b}$} & \multirow[t]{2}{*}{ Sum of ranks } \\
\hline & & value & rank & value & rank & \\
\hline TG-97-403 & 16.95 & 0.13 & 1 & 0.07 & 1 & 2 \\
\hline 13-VIII-50 & 8.68 & 0.47 & 2 & 0.61 & 3 & 5 \\
\hline 13-VIII-45 & 7.97 & 0.61 & 5 & 0.64 & 4 & 9 \\
\hline 13-VIII-27 & 5.57 & 0.53 & 3 & 1.92 & 7 & 10 \\
\hline 13-VIII-10 & 20.20 & 0.91 & 8 & 0.49 & 2 & 10 \\
\hline 13-VIII-60 & 11.67 & 0.70 & 6 & 1.22 & 5 & 11 \\
\hline 13-VIII-49 & 14.72 & 0.57 & 4 & 2.28 & 9 & 13 \\
\hline Satina & 17.79 & 0.81 & 7 & 1.25 & 6 & 13 \\
\hline Tajfun & 9.23 & 0.93 & 9 & 2.09 & 8 & 17 \\
\hline Jelly & 11.96 & 1.59 & 10 & $7.22 *$ & 10 & 20 \\
\hline
\end{tabular}

Significant: ${ }^{*}$ at $P<0.05$

${ }^{\mathrm{a}} A S V$ AMMI stability value

${ }^{\mathrm{b}} \mathrm{F}_{\mathrm{G} \times \mathrm{E}}$ - statistic $\mathrm{F}$ for interaction $\mathrm{G} \times \mathrm{E}$ (mixed model of ScheffeCaliński)
After PCA, the genotypes showing the highest contribution in variability caused by $\mathrm{G} \times \mathrm{E}$ were found and these were located at larger distances from the centre of the biplot. These genotypes are 13-VIII-10, 13-VIII-50, TG-97-403, and Satina. The smallest contribution was found for Jelly and Tajfun (Fig. 3 and Table 9). The environments may be grouped according to year with exception of environments B_15 and C_14 (Fig. 3).

The second stability parameter was obtained by applying the Scheffe-Caliński model. ANOVA revealed that the main effects G, L and Y accounted for 30\%, $11 \%$ and $0 \%$ of total SS, respectively. As for interactions involving $\mathrm{G}(\mathrm{G} \times \mathrm{L}, \mathrm{G} \times \mathrm{Y}$ and $\mathrm{G} \times \mathrm{E})$, they accounted for $11 \%-14 \%$ of total SS) (Table 7).

The last step was to assess the impact of individual genotypes on interactions. Only for three genotypes (13-VIII-10, 13 -VIII-50 and Satina), the highly significant values of $F_{\mathrm{G} \times \mathrm{E}}$ were found, which indicated their significant contribution to the observed $\mathrm{G} \times \mathrm{E}$ (Table 9). None of the genotypes had a significant contribution to the interactions $\mathrm{G} \times \mathrm{Y}$ and $\mathrm{G} \times \mathrm{L}$.

The correlation between both stability parameters $\mathrm{F}_{\mathrm{G} \times \mathrm{E}}$ and ASV was different from that obtained for TC and was only moderate $\left(r_{s}=0.47\right)$.

\section{Discussion}

\section{Concentration of Carotenoids}

The obvious statement is that the improvement of potato nutritional value of potato may be achieved by breeding methods. The prerequisite is the presence of variability in the trait of interest in the available breeding pool of potato. In the case of carotenoids such variability was found in various genetics pools (Andre et al. 2007; Brown et al. 1993; 
Fig. 3 Biplot for 10 potato genotypes grown at 8 different environments for lutein concentration

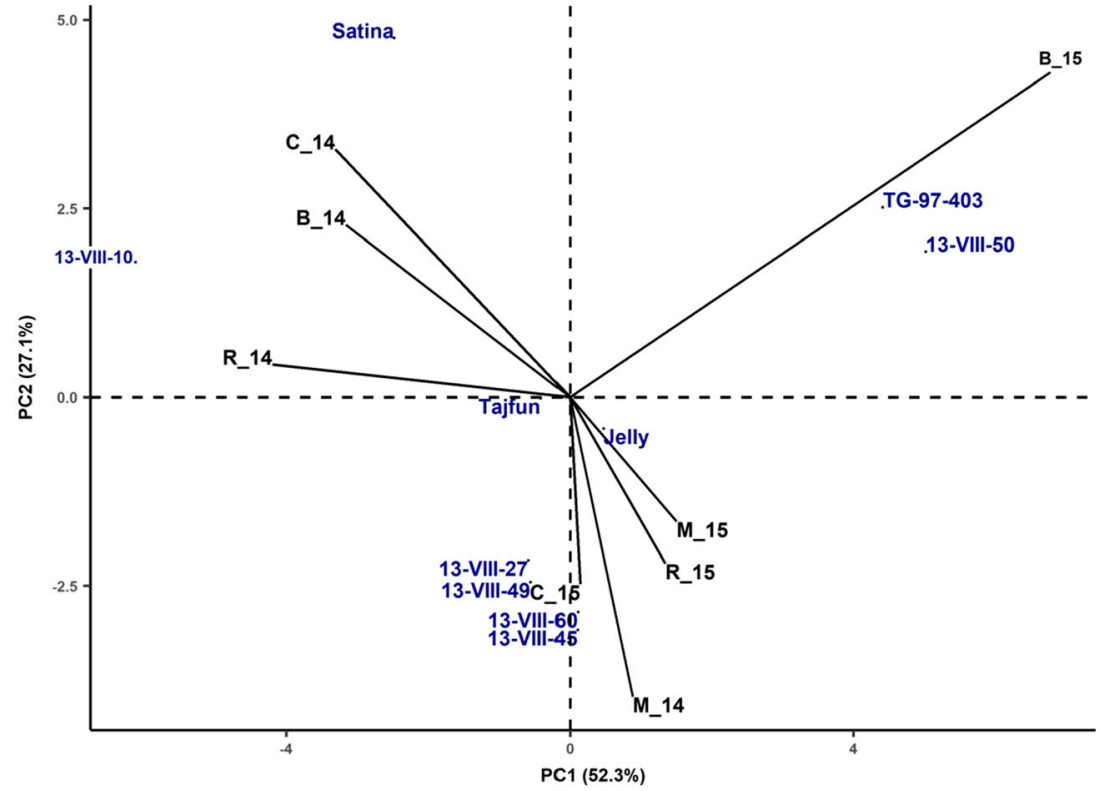

Breithaupt and Bamedi 2002; Burlingame et al. 2009; Haynes et al. 2010; Iwanzik et al. 1983; Lu et al. 2001).

In the presented study, the six of evaluated breeding lines are derived from crosses involving pollen parent with increased TC concentration in tubers (in the case of line 13VIII-45 both parents have increased level of TC). These lines had significantly increased concentrations of TC (up to $20.2 \mathrm{mg} \mathrm{kg}^{-1} \mathrm{FW}$ ) as compared with the parent with the low TC (up to $6.5 \mathrm{mg} \mathrm{kg}^{-1} \mathrm{FW}$ ), but only when the flesh of their tubers was yellow. The close relation between yellowness of tuber flesh and carotenoids level was found by many authors (Brown et al. 1993; Brown 2005; Brown et al. 2005, 2006, 2007, 2008; Nesterenko and Sink 2003; Van Eck et al. 2007) as well as in this study, as indicated by a very high correlation coefficient between TC and yellowness index.
It can be concluded that breeder may expect increases of TC concentration in tubers of progeny clones if at least one of their parents is characterised by an increased level of TC and individuals with yellow flesh are selected.

One of the tested clones TG-97-403 was derived from a different breeding program and had a significant contribution of $S$. phureja, which is a potential source of high concentration of carotenoids. Moreover, the tuber flesh of TG-97-403 was as yellow as tuber flesh of 13-VIII-10, which was outstanding in both YI value and TC concentration. Despite the fact that TG97-403 has clearly yellow tuber flesh and $S$. phureja in its pedigree, the concentrations of carotenoids were lowered as compared to what could be found in $S$. phureja and the respective concentrations of TC, lutein and zeaxanthin were $16.95 \mathrm{mg} \mathrm{kg}^{-1} \mathrm{FW}, 5.39 \mathrm{mg} \mathrm{kg}^{-1} \mathrm{FW}$ and $1.55 \mathrm{mg} \mathrm{kg}^{-1}$
Table 9 ASV and $\mathrm{F}_{\mathrm{G} \times \mathrm{E}}$ for lutein concentration $\left(\mathrm{mg} \mathrm{kg}^{-1} \mathrm{FW}\right)$ in potato tubers evaluated in 8 environments

\begin{tabular}{|c|c|c|c|c|c|c|}
\hline \multirow[t]{2}{*}{ Genotype } & \multirow[t]{2}{*}{ Mean lutein content } & \multicolumn{2}{|l|}{$\mathrm{ASV}^{\mathrm{a}}$} & \multicolumn{2}{|l|}{$\mathrm{F}_{\mathrm{G} \times \mathrm{E}}{ }^{\mathrm{b}}$} & \multirow[t]{2}{*}{ Sum of ranks } \\
\hline & & value & rank & value & rank & \\
\hline 13-VIII-27 & 2.94 & 2.31 & 3 & 0.56 & 1 & 4 \\
\hline Tajfun & 3.46 & 0.56 & 1 & 2.47 & 6 & 7 \\
\hline 13-VIII-49 & 3.59 & 2.56 & 4 & 1.76 & 3 & 7 \\
\hline 13-VIII-45 & 2.93 & 3.09 & 6 & 1.46 & 2 & 8 \\
\hline Jelly & 3.25 & 0.78 & 2 & 3.04 & 7 & 9 \\
\hline 13-VIII-60 & 3.13 & 2.85 & 5 & 2.32 & 5 & 10 \\
\hline TG-97-403 & 5.39 & 6.63 & 8 & 1.92 & 4 & 12 \\
\hline Satina & 6.02 & 5.87 & 7 & $8.61 * *$ & 8 & 15 \\
\hline 13-VIII-50 & 3.81 & 7.24 & 9 & $10.13 * *$ & 9 & 18 \\
\hline 13-VIII-10 & 6.66 & 8.69 & 10 & $15.15^{* *}$ & 10 & 20 \\
\hline
\end{tabular}

Significant: ${ }^{*}$ at $P<0.05$ and $^{* *}$ at $P<0.01$

${ }^{\mathrm{a}, \mathrm{b}}$ see the footnote of Table 7 
FW. The various clones or cultivars of $S$. phureja were quite extensively tested for carotenoids content (Bonierbale et al. 2009; Brown et al. 1993; Griffiths et al. 2007; Lu et al. 2001; Morris et al. 2004) and in some cases the levels total and individual carotenoids were very high. Bonierbale et al. (2009) identified S. phureja clones, in which the TC content exceeded $200 \mathrm{mg} \mathrm{kg}^{-1} \mathrm{FW}$, zeaxanthin content exceeded $100 \mathrm{mg} \mathrm{kg}^{-1} \mathrm{FW}$ and lutein content reached $19 \mathrm{mg} \mathrm{kg}^{-1} \mathrm{FW}$.

The number of individual carotenoids evaluated during the study was limited. However, lutein seems to be one of the major carotenoids in the examined tubers (on average $35 \%$ of TC) or may be even one of the dominant components of TC in white fleshed tubers (up to 55\% of TC). A higher proportion of lutein in white fleshed potatoes was observed by Haynes et al. (2010). This was also found in cultivars in which tuber flesh color is determined by anthocyanin pigments (Hamouz et al. 2016; Hejtmánková et al. 2013). Brown et al. (2008) found the lutein as a main carotenoid in potatoes. However, the prevalence of lutein in TC content was also found in yellow fleshed tubers of $S$. phureja cultivars (Burmeister et al. 2011; Hejtmánková et al. 2013).

The second carotenoid was zeaxanthin, which variation cannot be evaluated; its concentration was low and very frequently below LOQ, which was observed mainly in whitefleshed breeding lines and in tubers grown in the conventional location M in 2014 (the lowest average TC content was recorded), but also in environments with not so low average TC content as in tubers from organic location R in 2015. The proportion of zeaxanthin in tested tubers was estimated to be rather low and the highest was found in breeding lines 13VIII-10 and TG-97-403, both having the highest values of YI. The latter line has $S$. phureja in origin and in this species high concentrations of zeaxanthin were found (Brown et al. 1993; Breithaupt and Bamedi 2002; Bonierbale et al. 2009).

\section{Influence of Environmental Effects}

Purchasers of organic food assume that organic farming practice positively affects its nutritional properties. However, the findings of studies comparing concentration of specific nutrients between conventionally and organically grown foods usually are not conclusive (e.g. Bourn and Prescott 2002). There are two questions about nutritional value of organic food. The first is, whether the level of compounds important for nutritional value may be increased in organic conditions, which is crucial for proponents of organic farming. The second question is, whether the nutritional value of cultivars remains unchanged in a new cultivation system, taking into account that new potato cultivars are selected on the basis of field trials, which are still under traditional cultivation system.

The relationship between farming system and concentration of the health-promoting food ingredients is not well recognized. The available experimental evidence does not provide unequivocal conclusions about the effects of organic farming on concentrations of such ingredients. The increase of carotenoids content due to applying organic cultivation was not observed (Murniece et al. 2012 in potato; e.g. Søltoft et al. 2011 in carrot) or, on the contrary, a decrease was found, as in the case of red pepper (Daood et al. 2006) or potato (Wierzbicka and Hallmann 2013). In the presented study, the effect of cultivation system cannot be directly compared, because the different systems were not applied in the same locations. However, the observed variability of TC content did not show a clear pattern associated with the cultivation system, and in particular it was not shown that TC content increased under organic conditions. The highest TC content was observed in conventional location $\mathrm{B}$ in 2015 and 2016. In turn, in 2014, the TC concentration was lowered in all locations as compared to 2015 and 2016, and the lowest concentrations were found in tubers from both conventional and organic locations, $\mathrm{M}$ and $\mathrm{R}$ respectively.

With regard to lutein, the fluctuations of its content depended rather on location than year, which was confirmed by the ANOVA results (ANOVA according to the mixed model).

The effects of environmental factors on the accumulation of carotenoids in potato tubers were rarely evaluated. Usually, authors of these studies found that carotenoids concentration depend on genotype and various environmental factors (Haynes et al. 2010; Hejtmánková et al. 2013; Hamouz et al. 2016; Kotíková et al. 2007; Othman 2009; Payyavula et al. 2012; Reddivari et al. 2007; Tatarowska et al. 2014), but sometimes an influence of environment was not found (Brown et al. 2008). In the presented study, the environmental effects were slightly higher (in the case of TC) or clearly lowered (in the case of lutein) as compared to the effect of genotype. The mixed model of ANOVA enabled a more thorough analysis of environmental effects as compared to ANOVA in AMMI, since the impacts of years and locations were evaluated separately. In the case of TC, the predominant was the effect of year. With respect to lutein, the effect of location was most important, while the effect of year was insignificant.

The final step was the analysis of the $\mathrm{G} \times \mathrm{E}$ interaction by applying two methods, what lead to identifying genotypes with a stable expression of the tested traits. In the case of carotenoids, such analyses of $\mathrm{G} \times \mathrm{E}$ interaction were rarely carried out (Haynes et al. 2010; Tatarowska et al. 2014). A stable genotype is regarded a genotype with an insignificant contribution to this interaction. However, in each of the applied methods $\mathrm{G} \times \mathrm{E}$ is analyzed differently. In the case of the Scheffé-Caliński mixed model, the contribution of each genotype in the highest order interaction $\mathrm{G} \times \mathrm{Y} \times \mathrm{L}$ was measured by $\mathrm{F}$ statistics, which are stability parameters. The lower order interactions involving $\mathrm{G}$ (i.e. $\mathrm{G} \times \mathrm{L}$ and $\mathrm{G} \times \mathrm{Y}$ ) were tested separately, and for most genotypes in presented study were insignificant for both TC (with two exceptions) and lutein. In the case of AMMI, the inference about stability is possible after PCA applied for the effects of $\mathrm{G} \times \mathrm{E}$. 
Despite these differences, in the case of TC both methods turned out to give a fairly consistent ranking of genotypes in terms of stability. The most stable level of TC in various environments was expressed by the breeding line TG-97-403. This line is characterized by a significant proportion of S. phureja in its origin, in contrast to all other tested breeding lines and cultivars. The most unstable level of TC was found in tubers of Jelly, for which both indicators consistently pointed to instability.

In the case of stability of lutein concentration, both methods indicated almost the same most unstable genotypes. The only exception was TG-97-403, which was unstable according to AMMI and stable according to the mixed model. The ranking of other genotypes depends on the method. The variability of the ranking of genotypes depending on the applied method of stability assessment is often found (Adugna and Labuschagne 2003; Francis and Kannenberg 1978). The best solution is to use few methods and select the most stable genotypes on the basis of the sum of ranks (Ahmadi et al. 2015).

However, the most outstanding result obtained for the lutein, is that the ranking of genotypes is completely different from that obtained for TC concentration. The example of this is 'Jelly', which was the most unstable genotype as regards TC concentration and was among the most stable in the lutein content.

\section{Conclusion}

The presented study proved that the total content of carotenoids in potato tubers is significantly affected by environmental factors that cannot be controlled, because these are usually related to the year of cultivation. However, the level of lutein, carotenoid especially important for human health, was affected mainly by location. The direct evidence of the impact of the cultivation system is not provided, however, there are indications that the effects of the year and location play the most important role in controlling the accumulation of carotenoids in tubers. Despite the influence of these usually uncontrolled factors, it was possible to identify genotypes with an increased and stable level of TC or lutein in tubers. Although TC and lutein content were highly correlated, the analysis of stability indicated that genotypes stable in TC and in lutein content were not the same. The plant factors controlling the stable levels of various carotenoids may respond in different ways depending on type of carotenoids and environmental factors.

In terms of stable expression and content of total carotenoids, the outstanding was the breeding line, which originates from South American germplasm. This indicate how important is broadening of genetic base for improvement of nutrition value of potato.

Acknowledgements The project was financed by the resources of National Science Centre Poland granted based on a decision number DEC-2013/11/B/NZ9/00778.
Open Access This article is distributed under the terms of the Creative Commons Attribution 4.0 International License (http:// creativecommons.org/licenses/by/4.0/), which permits unrestricted use, distribution, and reproduction in any medium, provided you give appropriate credit to the original author(s) and the source, provide a link to the Creative Commons license, and indicate if changes were made.

\section{References}

Adugna, W., and M.T. Labuschagne. 2003. Parametric and nonparametric measures of phenotypic stability in linseed (Linnum usitatissimum L.). Euphytica 129 (2): 211-218.

Ahmadi, J., B. Vaezi, A. Shaabani, K. Khademi, S. Fabriki Ourang, and A. Pour-Aboughadareh. 2015. Non-parametric measures for yield stability in grass pea (Lathyrus sativus L.) advanced lines in semi warm regions. Journal of Agricultural Science and Technology 17: 1825-1838.

Andre, C.M., M. Oufir, C. Guignard, L. Hoffmann, J.F. Hausman, D. Evers, and Y. Larondelle. 2007. Antioxidant profiling of native Andean potato tubers (Solanum tuberosum L.) reveals cultivars with high levels of $\beta$ carotene, $\alpha$-tocopherol, chlorogenic acid and petanin. Journal of Agricultural and Food Chemistry 55 (26): 10839-10849.

ASTM (American Society for Testing and Materials). 2005 E 313 - 05 Standard Practice for Calculating Yellowness and Whiteness Indices from Instrumentally Measured Color Coordinates. West Conshohocken, PA: ASTM International.

Bonierbale, M., W. Grüneberg, W. Amoros, G. Burgos, E. Salas, E. Porras, and T. Zum Felde. 2009. Total and individual carotenoid profiles in Solanum phureja cultivated potatoes: II. Development and application of near-infrared reflectance spectroscopy (NIRS) calibrations for germplasm characterization. Journal of Food Composition and Analysis 22 (6): 509-516.

Bourn, D., and J. Prescott. 2002. A comparison of the nutritional value, sensory qualities, and food safety of organically and conventionally produced foods. Critical Review of Food Science and Nutrition 42 (1): $1-34$.

Breithaupt, D.E., and A. Bamedi. 2002. Carotenoids and carotenoid esters in potatoes (Solanum tuberosum L.): New insights into an ancient vegetable. Journal of Agricultural and Food Chemistry 50 (24): 7175-7181.

Brown, C.R. 2005. Antioxidants in potato. American Journal of Potato Research 82 (2): 163-172.

Brown, C.R. 2008a. Breeding for phytonutrient enhancement of potato. American Journal of Potato Research 85: 298-307.

Brown, C.R. 2008b. Achieving phytonutrient enhancement in a potato by breeding for increased pigment. In Color quality of fresh and processed foods, ed. C.A. Culver and R.E. Wrolstad, 102-111. Washington. DC: ACS Symposium Series 983. American Chemical Society.

Brown, C.R., C.G. Edwards, C.P. Yang, and B.B. Dean. 1993. Orange flesh trait in potato: Inheritance and carotenoid content. Journal of the American Society for Horticultural Science 118 (1): 145-150.

Brown, C.R., D. Culley, C.P. Yang, R. Durst, and R. Wrolstad. 2005. Variation of anthocyanin and carotenoid contents and associated antioxidant values in potato breeding lines. Journal of the American Society for Horticultural Science 130 (2): 174-180.

Brown, C.R., T.S. Kim, Z. Ganga, K. Haynes, D. De Jong, M. Jahn, I. Paran, and W. De Jong. 2006. Segregation of total carotenoid in high level potato germplasm and its relationship to beta-carotene hydroxylase polymorphism. American Journal of Potato Research 83 (5): 365-372.

Brown, C.R., D. Culley, M. Bonierbale, and W. Amorós. 2007. Anthocyanin. Carotenoid content and antioxidant values in native south American potato cultivars. HortScience 42 (7): 1733-1736.

Brown, C.R., R.W. Durst, R. Wrolstad, and W. De Jong. 2008. Variability of phytonutrient content of potato in relation to growing location and cooking method. Potato Research 51 (3-4): 259-270. 
Burlingame, B., B. Mouillé, and R. Charrondiere. 2009. Nutrients, bioactive non-nutrients and anti-nutrients in potatoes. Journal of Food Composition and Analysis 22 (6): 494-502.

Burmeister, A., S. Bondiek, L. Apel, C. Kuhne, S. Hillenbrand, and P. Fleischmann. 2011. Comparison of carotenoid and anthocyanin profiles of raw and boiled Solanum tuberosum and Solanum phureja tubers. Journal of Composition and Analysis 24: 865-872.

Caliński, T., S. Czajka, Z. Kaczmarek, P. Krajewski, and I. Siatkowski. 1998. Statistical methodology and usage of the program SERGEN (version 3 for windows 95) dedicated to analysis of series of plant genetic and breeding experiments. Poznań: IGR PAN.

Daood, H.G., R. Tomoskozi-Farkas, and J. Kapitany. 2006. Antioxidant content of bio and conventional spice red pepper (Capsicum annuит L.) as determined by HPLC. Acta Agronomica Hungarica 54 (2): 133-140.

De Mendiburu, F. 2015 Agricolae: Statistical Procedures for Agricultural Research. R Package Version 1.2-4. https://CRAN.R-project.org/ package=agricolae. Accessed 17 April 2018.

Ezekiel, R., N. Singh, S. Sharma, and A. Kaur. 2013. Beneficial phytochemicals in potato - A review. Food Research Intern487ational 50 (2): -496

Faostat, Food and Agriculture Organization of the United Nations 2019 (http://faostat.fao.org). Accessed 17 April 2019

Fasahat, P., A. Rajabi, S.B. Mahmoudi, M.A. Noghabi, and J.M. Rad. 2015. An overview on the use of stability parameters in plant breeding. Biometrcs \& Biostatistcs International Journal 2 (5): 00043.

Francis, T.R., and L.W. Kannenberg. 1978. Yield stability studies in short-season maize. I. A descriptive method for grouping genotypes. Canadian Journal of Plant Science 58 (4): 1029-1034.

Gauch, H.G. 2006. Statistical analysis of yield trials by AMMI and GGE. Crop Science 46 (4): 1488-1500.

Griffiths, D.W., M.F.B. Dale, W.L. Morris, and G. Ramsay. 2007. Effects of season and postharvest storage on the carotenoid content of Solanum phureja potato tubers. Journal of Agricultural and Food Chemistry 55 (2): 379-385.

Hamouz, K., K. Pazderu, J. Lachman, J. Čepl, and Z. Kotíková. 2016. Effect of cultivar, flesh colour, locality and year on carotenoid content in potato tubers. Plant, Soil and Environment 62 (2): 86-91.

Harrel, Jr. F.E., with contributions from Charles Dupont and many others. 2016. Hmisc: Harrell Miscellaneous. R package version 4.0-2. https://CRAN.R project.org/package Hmisc. Accessed 17 April 2019

Haynes, K.G., B.A. Clevidence, D. Rao, B.T. Vinyard, and J.M. White. 2010. Genotype $\times$ environment interactions for potato tuber carotenoid content. Journal of the American Society for Horticultural Science 135 (3): 250-258.

Haynes, K.G., B.A. Clevidence, D. Rao, and B.T. Vinyard. 2011. Inheritance of carotenoid content in tetraploid $\times$ diploid potato crosses. Journal of the American Society for Horticultural Science 136 (4): 265-272.

Hejtmánková, K., Z. Kotíková, K. Hamouz, V. Pivec, J. Vacek, and J. Lachman. 2013. Influence of flesh colour, year and growing area on carotenoid and anthocyanin content in potato tubers. Journal of Food Composition and Analysis 32 (1): 20-27.

Iwanzik, W., M. Tevini, R. Stute, and R. Hilbert. 1983. Carotenoid content and composition of various German potato varieties and their importance for tuber flesh colour. Potato Research 26: 149-162.

Kotíková, Z., A. Hejtmankova, J. Lachman, K. Hamouz, E. Trnkova, and P. Dvorak. 2007. Effect of selected factors on total carotenoid content in potato tubers (Solanum tuberosum L.). Plant Soil and Environment 53 (8): 355

Landrum, J.T., and R.A. Bone. 2001. Lutein, zeaxanthin and macular pigment. Archives of Biochemistry and Biophysics 385 (1): 28-40.

Lu, W., K. Haynes, E. Wiley, and B. Clevidence. 2001. Carotenoid content and color in diploid potatoes. Journal of the American Society for Horticultural Science 126 (6): 722-726.
Mądry, W., and M.S. Kang. 2005. Scheffé-Caliński and Shukla models: Their interpretation and usefulness in stability and adaptation analyses. Journal of Crop Improvement 14 (1-2): 325-369.

Morris, W.L., L. Ducreux, D.W. Griffiths, D. Stewart, H.V. Davies, and M.A. Taylor. 2004. Carotenogenesis during tuber development and storage in potato. Journal of Experimental Botany 55 (399): 975-982.

Murniece, I., Z. Kruma, and I. Skrabule. 2012. Carotenoids and colour before and after storage of organically and conventionally cultivated potato genotypes in Latvia. World Academy of Science, Engineering and Technology. International Journal of Biological, Biomolecular, Agricultural, Food and Biotechnological Engineering 6 (7): 503-507.

Nesterenko, S., and K.C. Sink. 2003. Carotenoid profiles of potato breeding lines and selected cultivars. HortScience 38 (6): 1173-1177.

Othman, R. 2009. Biochemistry and genetics of carotenoid composition in potato tubers. Christchurch: Lincoln University. $\mathrm{PhD}$ thesis.

Payyavula, R.S., D.A. Navarre, J.C. Kuhl, A. Pantoja, and S.S. Pillai. 2012. Differential effects of environment on potato phenylpropanoid and carotenoid expression. BMC Plant Biology 12 (1): 39.

PN-90/A-75101/12. 1990. Fruit and vegetable products. Preparation of samples and physico-chemical test methods. Determination of total carotenoids and beta-carotene, PKN Warszawa [in Polish].

Purchase, J.L., H. Hatting, and C.S. Van Deventer. 2000. Genotype $\times$ environment interaction of winter wheat (Triticum aestivum L.) in South Africa: II. Stability analysis of yield performance. South African Journal of Plant and Soil 17 (3): 101-107.

R Core Team. 2015. $R$ : A language and environment for statistical computing [internet]. Vienna: R Foundation for Statistical Computing Available from: http://www.R-project.org/. Accessed 17 April 2019

Reddivari, L., A.L. Hale, and J.C. Miller. 2007. Genotype, location and year influence antioxidant activity carotenoid content phenolic content and composition in specialty potatoes. Journal of Agricultural and Food Chemistry 55 (20): 8073-8079.

Reyes, L.F., J.C. Miller, and L. Cisneros-Zevallos. 2005. Antioxidant capacity. Anthocyanins and total phenolics in purple-and red-fleshed potato (Solanum tuberosum L.) genotypes. American Journal of Potato Research 82 (4): 271-277.

Śliwka, J., H. Jakuczun, R. Lebecka, W. Marczewski, C. Gebhardt, and E. Zimnoch-Guzowska. 2006. The novel, major locus Rpi-phul for late blight resistance maps to potato chromosome IX and is not correlated with long vegetation period. Theoretical and Applied Genetics 113 (4): 685-695.

Søltoft, M., A. Bysted, K.H. Madsen, M.A. Budek, S.G. Bügel, J. Nielsen, and P. Knuthsen. 2011. Effects of organic and conventional growth systems on the content of carotenoids in carrot roots and on intake and plasma status of carotenoids in humans. Journal of the Science of Food and Agriculture 91 (4): 767-775.

Tatarowska, B., D. Milczarek, H. Jakuczun, A. Stochmal, Ł. Pecio, and B. Flis. 2014. The potential for the improvement of carotenoids level in potato - effect of the genotype and environment. Journal of Food, Agriculture and Environment 12 (2): 536-540.

Valcarcel, J., K. Reilly, M. Gaffney, and N. O’Brien. 2015. Total carotenoids and 1-ascorbic acid content in 60 varieties of potato (Solanum tuberosum L.) grown in Ireland. Potato Research 58 (1): 29-41.

Van Eck, J., B. Conlin, D.F. Garvin, H. Mason, D.A. Navarre, and C.R. Brown. 2007. Enhancing beta-carotene content in potato by RNAimediated silencing of the beta-carotene hydroxylase gene. American Journal of Potato Research 84 (4): 331-342.

Wickham, H. 2009. ggplot2: Elegant graphics for data analysis. Springer Verlag New York.

Wierzbicka, A., and E. Hallmann. 2013. Carotenoid content of potato tubers grown in the organic system. Journal of Research and Applications in Agricultural Engineering 58 (4): 223-227. 